\title{
Expanding our arsenal against an old foe
}

\author{
Marisa Cevasco, MD, MPH, ${ }^{\mathrm{a}}$ Jonathan Hastie, MD, ${ }^{\mathrm{b}, \mathrm{c}}$ and Hiroo Takayama, $\mathrm{MD}, \mathrm{PhD}^{\mathrm{a}}$
}

\footnotetext{
From the Divisions of ${ }^{\mathrm{a}}$ Cardiothoracic and Vascular Surgery, ${ }^{\mathrm{b}} \mathrm{Critical}$ Care Medicine, and ${ }^{\mathrm{c}}$ Adult Cardiothoracic Anesthesiology, Columbia University Medical Center, New York, NY.

Disclosures: Authors have nothing to disclose with regard to commercial support.

Received for publication Feb 15, 2018; accepted for publication Feb 15, 2018; available ahead of print March 13, 2018 .

Address for reprints: Hiroo Takayama, MD, PhD, Division of Cardiothoracic and Vascular Surgery, Columbia University Medical Center, 177 Fort Washington Ave, New York, NY 10032 (E-mail: ht2225@cumc. columbia.edu)

J Thorac Cardiovasc Surg 2018;156:694-5

$0022-5223 / \$ 36.00$

Copyright $(2) 2018$ by The American Association for Thoracic Surgery

https://doi.org/10.1016/j.jtcvs.2018.02.046
}

Ventilator-associated pneumonia (VAP) is a formidable foe. As the most common infection in patients in the intensive care unit, VAP occurs more frequently in postoperative patients than in medical patients. ${ }^{1}$ VAP is associated with longer hospital stays and higher costs: on average, patients remain intubated 4 additional days, are hospitalized 2 additional days, and incur additional health care costs of $\$ 40,000$ per $_{\text {patient. }}{ }^{2}$ Because changes in the bacterial flora of the oropharynx are implicated in the pathophysiology of $\mathrm{VAP},{ }^{3}$ the current best preventive practice includes the implementation of care bundles to elevate the head of the bed, facilitate timely extubation, and provide oral care with chlorhexidine-based solutions. ${ }^{4}$

In this issue of the Journal, Perez Granda and colleagues ${ }^{5}$ renew our interest in an old ally. Selective digestive decontamination (SDD) involves a regimen of nonabsorbable antimicrobial agents in the oropharynx and gastrointestinal tract and maintenance of anaerobic intestinal flora by minimizing antianaerobic antibiotics. Protocols may also include a brief course of intravenous antibiotics. ${ }^{6}$ The first reported clinical use of SDD dates back to 1983, when it was demonstrated to prevent severe infections and reduce morbidity in critically ill intensive care unit patients. ${ }^{7}$ In the current study of Perez Granda and colleagues, ${ }^{5}$ after a baseline period between August 2012 and August 2013, during which the VAP prevention bundle included the measures already described, with the addition of subglottic suctioning, SDD was systematically added for all cardiac surgical patients from September 2013 to January 2015.

Recent meta-analyses have demonstrated that SDD has a favorable effect on mortality among adults in general intensive care units ${ }^{8}$ as well as patients with burns, ${ }^{9}$ although interpretation is limited by study heterogeneity, and application is limited by low levels of antibiotic resistance. ${ }^{10}$ In the observations of Perez Granda and colleagues, ${ }^{5}$ the addition of SDD to standard VAP preventive measures decreased the incidence of lower respiratory tract infections (VAP and tracheobronchitis) by $50 \%$ both in all cardiac surgical patients and specifically in those who received

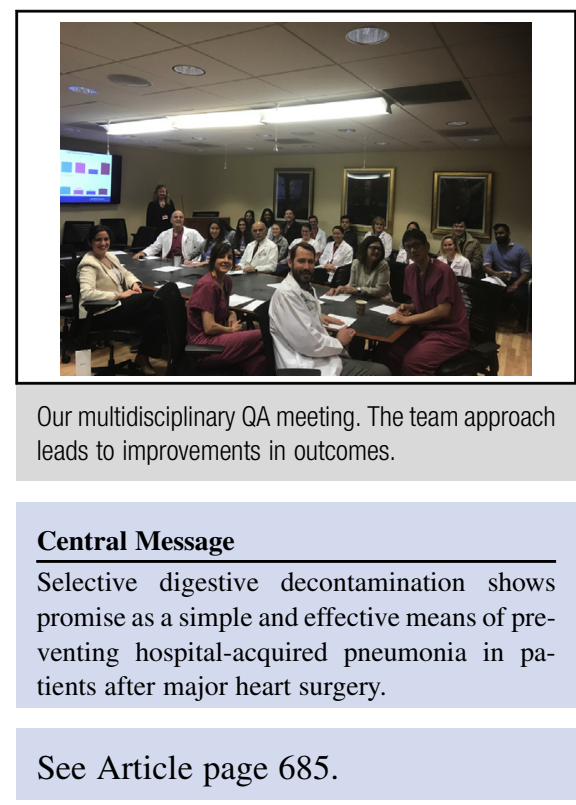

mechanical ventilatory support for longer than 48 hours. Despite the reduction in incidence in VAP, the median ventilator time for those who received mechanical ventilatory support was unchanged at 6 days.

Concerns about development of bacterial resistance have hampered the widespread adoption of SDD, ${ }^{11}$ particularly because substantial evidence is based on populations in areas with low levels of antibiotic resistance. ${ }^{10}$ Comparing patient groups before and after implementation of SDD, Perez Granda and colleagues ${ }^{5}$ noted no difference in number of patients with carbapenemase-producing gram-negative bacteria or patients with methicillin-resistant Staphylococcus aureus, and they saw a non-statistically significant reduction in number of patients with resistant Pseudomonas aeruginosa. General trends in antibiotic use and hospital flora are not described in this article. The effects of SDD in areas with higher levels of resistance require additional study.

It is promising news that a simple and low-cost strategy such as SDD may reduce the incidence of VAP among patients undergoing cardiac surgery. The paucity of evidence pointing to the expansion of drug-resistant organisms is also encouraging. Confirmation of the effects of SDD in randomized, controlled trials may reveal one of our most effective yet currently underused tools to prevent VAP.

\section{References}

1. Dudeck MA, Weiner LM, Allen-Bridson K, Malpiedi PH, Peterson KD, Pollock DA, et al. National Healthcare Safety Network (NHSN) report, data sum mary for 2012, device-associated module. Am J Infect Control. 2013;41:1148-66. 
2. Kollef MH, Hamilton CW, Ernst FR. Economic impact of ventilator-associated pneumonia in a large matched cohort. Infect Control Hosp Epidemiol. 2012; 33:250-6.

3. Garrouste-Orgeas M, Chevret S, Arlet G, Marie O, Rouveau M, Popoff N, et al. Oropharyngeal or gastric colonization and nosocomial pneumonia in adult intensive care unit patients a prospective study based on genomic DNA analysis. Am J Respir Crit Care Med. 1997;156:1647-55.

4. Evans B. Best-practice protocols: VAP prevention. Nurs Manage. 2005;36:10, 12, 14 passim.

5. Perez Granda MJ, Barrio JM, Hortal J, Burillo A, Munoz P, Bouza E. Impact of selective digestive decontamination without systemic antibiotics in a major heart surgery intensive care unit. J Thorac Cardiovasc Surg. 2018;156:685-93.

6. Price R, MacLennan G, Glen J, SuDDICU Collaboration. Selective digestive and oropharyngeal decontamination and topical oropharyngeal chlorhexidine for prevention of death in general intensive care: systematic review and network metaanalysis. BMJ. 2014;348:g2197.
7. Stoutenbeek CP, van Saene HK, Miranda DR, Zandstra DF. A new technique of infection prevention in the intensive care unit by selective decontamination of the digestive tract. Acta Anaesthesiol Belg. 1983;3:209-21.

8. Rubio-Regidor M, Martín-Pellicer A, Silvestri L, van Saene HK, Lorente JA, de la Cal MA. Digestive decontamination in burn patients: a systematic review of randomized clinical trials and observational studies. Burns. 2018;44: 16-23.

9. Plantinga NL, de Smet AM, Oostdijk EA, de Jonge E, Camus C, Krueger WA, et al. Selective digestive and oropharyngeal decontamination in medical and surgical ICU patients: individual patient data meta-analysis. Clin Microbiol Infect. September 1, 2017 [Epub ahead of print].

10. Plantinga NL, Bonten MJ. Selective decontamination and antibiotic resistance in ICUs. Crit Care. 2015;19:259.

11. Silvestri L, van Saene HK. Selective decontamination of the digestive tract: an update of the evidence. HSR Proc Intensive Care Cardiovasc Anesth. 2012;4: 21-9. 